\title{
Team Assisted Individualization Model Assisted by Effective Ludo Media Improving Student Learning Outcomes
}

\author{
Donna Restu Wilujeng \\ Program Studi Pendidikan Guru Sekolah Dasar, FIP, Upgris, Semarang, Indonesia \\ Email: donnarestuw@gmail.com \\ Sukamto \\ Program Studi Pendidikan Guru Sekolah Dasar, FIP, Upgris, Semarang, Indonesia \\ Email: sukamto@upgris.ac.id \\ Ervina Eka Subekti \\ Program Studi Pendidikan Guru Sekolah Dasar, FIP, Upgris, Semarang, Indonesia \\ Email:vina140310@gmail.com
}

\section{A R T I C L E I N F O \\ Article history: \\ Article history: \\ 1 Mei 2020 Received in \\ revised form \\ 11 Juni 2020 \\ Accepted 10 Juli 2020 \\ Available online 25 Agustus \\ 2020 \\ Kata Kunci: \\ Hasil belajar, \\ kemampuan pemecahan \\ masalah, team assisted \\ individualization, ludo}

\author{
Keywords: \\ Learning outcomes, \\ Problem solving skills, \\ team assisted \\ individualization, ludo
}

\begin{abstract}
A B S T R A K
Rendahnya kompetensi pengetahuan matematika yang disebabkan oleh kurang optimalnya penggunaan model pembelajaran menyebabkan siswa sulit memahami materi belajar. Tujuan penelitian ini yaitu menganalisis keefektifan model Team Assisted Individualization berbantu media ludo terhadap hasil belajar dilihat dari kemampuan pemecahan masalah materi pecahan. Jenis penelitian ini merupakan penelitian kuantitatif menggunakan pre-experimental design dengan bentuk one-group pretest-posttest design. Jumlah sampel dalam penelitian ini adalah seluruh siswa kelas IV yang berjumlah 26 siswa dengan menggunakan sampling jenis sampling jenuh. Pengumpulan data dalam penelitian ini diperoleh melalui wawancara, tes dan dokumentasi. Hasil analisis data diperoleh t_hitung9,698 dan t_tabel 1,706 dengan taraf signifikan 5\%. Karena t_hitung > t_tabel yaitu 9,698>1,706 sehingga H_0 ditolak yang artinya terdapat perbedaan hasil belajar pretest dan postest. Kemudian uji t dua pihak kemampuan pemecahan masalah menunjukan bahwa t_hitung > t_tabel yaitu $8,000>1,671$ maka H_0 ditolak, Jadi terdapa perbedaan yang signifikan hasil belajar dilihat dari kemampuan pemecahan masalahnya menggunakan model Team Assisted Individualization dengan kelompok yang dibelajarkan dengan omodel konvensial pada kelas IV SD. Model Team Assisted Individualization berbantu media Ludo efektif diterapkan dalam proses pembelajaran untuk meningkatkan hasil belajar pecahan siswa.
\end{abstract}

\begin{abstract}
A B S T R A C T
The low competence of mathematical knowledge caused by the lack optimal use of the learning model makes it difficult for students to understand the learning material. The purpose of this study was to analyze the effectiveness of the Team Assisted Individualization model assisted by Ludo media on learning outcomes in terms of the problem-solving ability of fraction material. This type of research was a quantitative study using pre-experimental design in the form of a one-group pretestposttest design. The number of samples in this study was all students of class IV, amounting to 26 students using saturated sampling type sampling. Data collection in this study was obtained through interviews, tests and documentation. The results of data analysis obtained tcount 9.698 and ttable 1.706 with a significant level of 5\%. Because t_count $>$ ttable is 9.698> 1.706, so H_0 is rejected, which means that there are differences in pretest and posttest learning outcomes. Then the twoparty t-test of problem-solving abilities shows that tcount> ttable is $8,000>1,671$ then $\mathrm{H}_{-} 0$ is rejected, so there is a significant difference in learning outcomes seen from the problem-solving ability using the Team Assisted Individualization model with groups that are taught with conventional models in grade IV SD. The Team Assisted Individualization model assisted by Ludo media is effectively applied in the learning process to improve student learning outcomes for fractions.
\end{abstract}

\section{Introduction}

Education is very important in an effort to improve and develop superior and broad-minded human resources (HR), as well as to develop the skills that are owned in him. Education will strive for a person's life to be better because there are changes in that person (Nurfitriana, 2015; Renny, Sonbay, Yohana, 2019). Through education, someone learns to be better. Learning is a process of effort made by a person to obtain a change in behavior for the better that is obtained from his experience (Slameto, 2010; Susanto, 2016). Education will produce changes that are permanent (permanent) in the habits of behavior, thoughts, and attitudes (Sudharto, 
2013). From this it can be seen that education is carried out to produce changes in enthusiastic behavior in learning that are permanent and inherent in themselves. In the world of education, one of the factors that influence student learning success is the teacher. During the learning process, the teacher plans an interesting learning process so that students can develop their potential and through teaching activities the teacher is able to prepare students to make learning as a provision for their life (Donas Ahmad Najib \&Elhefni, 2016; Donas \& Elhefni, 2016). One of the compulsories and very important subjects is mathematics.

At the elementary school level, mathematic is a very important subject. Mathematic lessons are needed in everyday life such as solving arithmetic problems. It makes a person get used to solve life's problems easily. Research conducted by Ismayani, Ani, \& Nuryanti (2016) stated that mathematics can equip students to become human beings who have the ability to think logically, systematically, analyze, critically, creatively and have the ability to work together. In this globalization era, it will require mastery and understanding of mathematics in everyday life. Based on this, it can be concluded that mathematics is needed in solving problems of everyday life. The important role of mathematics in life is that mathematics should be a fun and enjoyable subject for students (Mahendra, 2017; Suarsana, Supawidhiasih, \& Parwati, 2018). But many students do not like mathematics. This is confirmed by research conducted by Mahendra (2017) who stated that students do not like mathematics because they think the subject is very difficult and not easy to understand because there are many things that do not need to be solved, memorize formulas and interpret the language of mathematics.

Currently, many students experience problems in achieving optimal competency in mathematical knowledge. This was also expressed by (Anika \& Fajar, 2020; Ariawan \& Pratiwi, 2017) who stated that the learning process will not run optimally if there are only a few students who are active in learning. It makes learning in the classroom less attractive and monotonous. Indeed, interesting learning activities will make students motivated in learning so that the learning objectives will be maximally achieved. This is supported by the results of observations in one elementary school. Based on the results of observations made at SDN O1 Petanjungan in grade IV students, it was found that students were less enthusiastic in participating in the learning process; this was because the learning process used the lecture method and the lack of innovative media that helped students to learn. Based on the observations that have been made, students tended to find it difficult to do math problems. The dominant use of the lecture method and the lack of learning media will affect student learning outcomes. The results of the interview with the fourth-grade homeroom teacher indicated that there were 26 class IV students, with details of 15 female students and 11 male students. The KKM score set for the fourth-grade mathematics subject is 68 . The class average score was obtained during the daily math test of fraction material is 65 with the highest score being 74 and the lowest score being 54. Complete number of 10 students or $36.73 \%$ and 18 students or $63.27 \%$ incomplete It showed that many grade IV students have low learning outcomes, besides that students also did not understand and still have difficulty regarding the basic concepts of multiplication and division in mathematics. Students have difficulty understanding and solving problem. Students immediately wrote down their answers without writing down the steps to solve the problem.

Conventional learning causes the learning atmosphere to be less active because students only listen to explanations from the teacher. Therefore, the teacher plays an important role in managing the classroom and implementing innovative learning models so that students will be motivated to learn. The improvement of student learning outcomes depends on the role of the teacher in carrying out the learning process. Therefore, a teacher is required to have good teaching skills while delivering material in class; this ability can be seen when the learning process is active, fun and innovative which can be helped using learning media. Puspita, Asri, \& Ardana (2019) also stated that the teacher should choose and determine learning strategies so that learning objectives can be achieved. Research conducted by (Marliani, 2015; Trisnawati, 2019) who stated that the application of appropriate and innovative learning models can improve student learning outcomes. Kartika, dkk (2017) also stated that innovative learning models can increase student motivation in learning so that it affects student learning outcomes. One learning model that can be used by teachers to increase students' motivation in learning and solving student problems is the Team Assisted Individualization learning model.

The Team Assisted Individualization (TAI) learning model is one type of cooperative learning model that combines the advantages of cooperative learning and individual learning. This type is designed to solve student learning difficulties individually (Lestari, 2015; Siwi, Sudrajat, \& Wardana, 2019). Therefore, learning activities are more widely used to solve problems; the characteristic of this type of TAI is that each student individually learns the learning material that has been prepared by the teacher. Student learning outcomes are taken to groups to discuss and be discussed by group members and all group members are responsible for the overall answer as a shared responsibility. The Team Assisted Individualization (TAI) model can make students more active in learning mathematics. The steps contained in this model are the formation of small groups with group leaders who are able to help group members so that they can increase student activity in learning. Research conducted by Siwi, Sudrajat, \& Wardana (2019) also showed that learning by applying the TAI type cooperative learning model can improve student learning outcomes. The advantages of using the Team Assisted Individualization model are that students can be helped in solving problems and celever students develop their abilities and skills. 
There is responsibility in groups to solve problems that students are taught how to work together in a group, students can discuss or convey ideas until they are true understand correctly, and students have a sense of care and a sense of responsibility towards other friends in the learning process (Shoimin, 2014). Research conducted by (Farnika, Ikhsan, \& Sofyan, 2015; Siwi et al., 2019) stated that the cooperative learning model type Team Assisted Individualization affects the ability of students to understand and solve mathematical problems compared to using conventional learning.

Based on this description, it can be concluded that the Team Assisted Individualization learning model has an effect on student learning outcomes, especially in mathematics. Learning by applying the Team Assisted Individualization model has the specialty of being able to train cooperation and communication between students, because students learn in groups so as to minimize boredom in students during the learning process. This causes the learning process to be varied, active, and fun when compared to conventional learning models. Apart from the learning model, one other factor that supports student success is the learning media.

Learning media is the key in the learning process that is useful in delivering learning material so that students can easily digest learning material (Irwandi, 2020; Qondias \& Dkk, 2016). (Sundayana \& Rostina, 2014) stated that the media is a tool that functions to convey messages. There are many learning media that can be used to support the Team Assisted Individualization learning model, one of which is Ludo. Ludo media is a modified game where every point has a question card and the addition of motivational words, with the available question's students can get used to practicing doing the questions. Before implementing Ludo media learning, students must know some of the terms in this game, namely: a) Home, which is the starting point or starting place of the pawn before heading to the start. b) Start, which is the starting place after the pawn leaves the home. c) Circle plot, which is the place where the player must take the question card if he is on that tile. d) Plot of stars, which is a square that contains motivational words. e) Back, namely returning to the last place before moving. $\mathrm{f}$ ) Finish, which is the final place to stop the pawn. The advantages of this Ludo media include; a) The existence of groups of students can discuss to make it easier to solve problems. b) Train students' cooperation and socialization skills. c) In each question there is a point so that students will feel happy while learning. d) On Ludo's board there are motivational words to instill the concept that mathematics is fun so that students can prefer mathematics.

Research conducted by Jihan, Reffiane, \& Arisyanto (2019) stated that the advantages of Ludo game are traditional games that are fun, entertaining and easy to do by students so that they can improve student learning outcomes. Hapsari \& Suminar (2014) also stated that Ludo media is effective in increasing student motivation in learning so that student learning outcomes increase. Research conducted by Mufida \& Wiyatmo (2018) stated that the Ludo learning media can increase students' interest in learning so that learning objectives can be achieved optimally. The results of research conducted by Nisa \& Wiryanto (2019) also stated that there is a significant effect on learning outcomes with the presence of Ludo media in the learning process. So, it can be said that Ludo learning media has a positive influence on student learning outcomes because this media can increase student motivation in learning.

Based on this explanation, the research objective was formulated to analyze the effectiveness of the Team Assisted Individualization model assisted by Ludo media on learning outcomes seen from the problem-solving ability of fraction material. This research will combine the Team Assisted Individualization model with Ludo media that is suitable for fraction material. The steps are in accordance with the syntax of the Team Assisted Individualization model, namely (1) the teacher conveys learning objectives and motivates students in learning; (2) the teacher presents material and assigns students assisted by Ludo media in groups, (3) the teacher gives awards based on the acquisition of grades of the Ludo game. The steps of this learning model are combined with Ludo media. By applying the Team Assisted Individualization learning model, it is expected to improve student learning outcomes. This combination of models and media can be an alternative for teachers in developing and innovating interesting learning.

\section{Method}

This study used a pre-experimental design with a one-group pretest-posttest design. In this study, the pretest and posttest techniques were used. Pretest is a preliminary test to determine students' initial ability in the learning process before receiving the Teams Assisted Individualization learning model treatment. Then the researcher gave a posstest after giving the treatment using the Teams Assisted Individualization model. This posttest is the final test to determine the ability of students after being given treatment. Thus, the results of treatment can be known to be more accurate because it can compare with the conditions before being treated.

The population in this study was all fourth-grade students of SD Negeri 01 Petanjungan. In this sample there are 26 students consisting of 15 female students and 11 male students. The sampling technique was a saturated sampling technique because all members of the population were used as samples. Therefore, all fourthgrade students at SD Negeri 01 Petanjung were involved in the research process. 
The data collected in this study were students' mathematical knowledge competency data. Research data collection used in this research was the test method. The test is a measurement in the form of numbers, a scale or a categorical system of objective behavior (Yusuf, 2015). The test used in this study is a multiple-choice test. Students who answered correctly got a score of 1 , and students who answered incorrectly to the test items got a score of 0 .

Data collection techniques used non-test including interviews, observation and documentation. Researchers involved themselves in the situation of the subject under study before and during learning using documentation and written tests. The research instrument was in the form of an interview sheet, documentation of learning activities in the form of photos, the test includes the form of the test, the test preparation method, the test instrument test (validity, reliability, difficulty level, distinguishing power).

The data analysis method used was inferential statistical analysis method, namely t-test and completeness test. Before the $t$ test was carried out, the prerequisite test was carried out, namely the normality test. This normality test used the Liliefors test.

\section{Result and Discussion}

In the pretest results of 26 students there were 23 students who did not complete and 3 students completed. Whereas in the posttest results, there were 5 students who did not complete and 21 students completed the posttest. Students who did not complete were seen from the KKM score of 68. The following results from the students' pretest and posttest scores were processed and the following scores were obtained:

Table 1 Recapitulation of pretest and posttest scores

\begin{tabular}{|c|c|c|}
\hline Information & Pretest Score & Posttest Score \\
\hline Lowest score & 46 & 60 \\
\hline The highest score & 73 & 96 \\
\hline Average & 60,54 & 80,96 \\
\hline Percentage increase & & $20,42 \%$ \\
\hline
\end{tabular}

From table 1, it is found that the average test score before being given treatment is 60.54 with 23 students declared incomplete and 3 students declared complete. After being given learning with the Teams assisted individualization learning model, the average posttest score of students was 80.96 with 5 students declared incomplete and 3 students declared complete. The percentage increase is $20.42 \%$. The conclusion from the above explanation can be seen that the initial ability is obtained on a relatively low average. After being given treatment using the Teams Assisted Individualization model, there was an increase in student learning outcomes. This can be seen in the diagram image below:

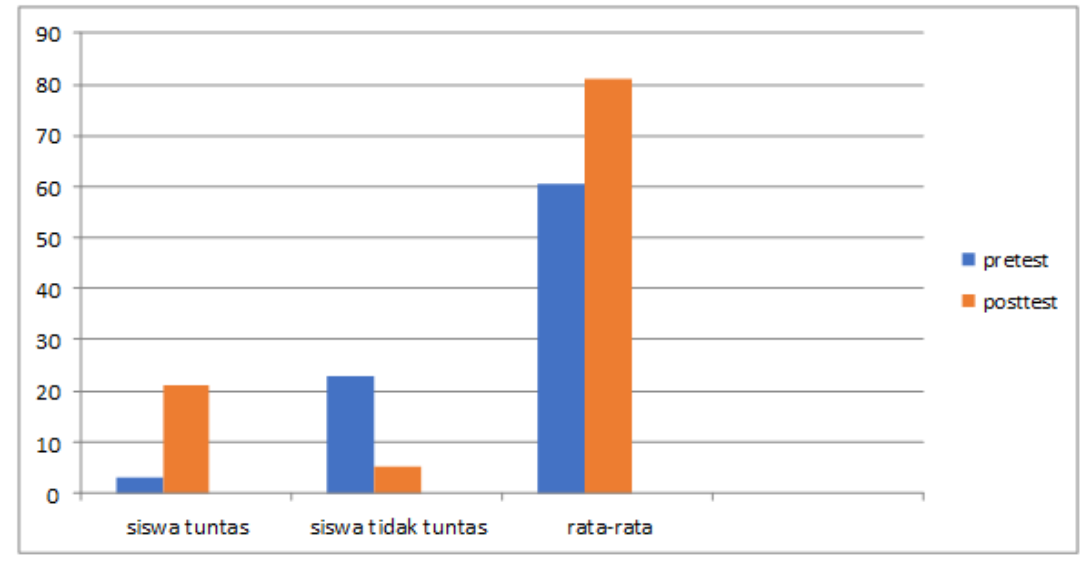

Gambar 1. Nilai pretest dan postest

An average test value before being given the treatment of 60.54 with 23 students declared incomplete and 3 students declared complete. After being given learning with the Teams assisted individualization learning model, the average posttest score of students was 80.96 with 5 students declared incomplete and 3 students declared complete. The percentage increases up to $20.42 \%$. The conclusion from the above explanation can be 
seen that the initial ability is obtained on a relatively low average. After being given treatment using the Teams Assisted Individualization model, there was an increase in student learning outcomes.

After it is known that the posttest results have increased, then the initial and final data normality test is carried out, one-party $t$ test, two-party $t$ test and learning completeness test. The initial data normality test calculated is the pretest value to find out whether the data is normally distributed or not. This normality test used the Liliefors test with a significant level of 5\%. The following is a recapitulation of the initial normality test as follows:

Table 2. Recapitulation of the initial normality test

\begin{tabular}{ccc}
\hline Data & Learning Outcomes & Conclusion \\
\hline Lo & 0,104 & Normal distribution \\
Ltabel & 0,174 & \\
\hline
\end{tabular}

Based on the data in table 1 that at the level of $5 \%$ and $n=26$, it is obtained L_0 (0.104) <Ltable $(0.174)$, so H_O is accepted, indicating that the data comes from a normally distributed population. The final data normality test that is calculated is the posttest value to determine whether the data is normally distributed or not. This normality test uses the Liliefors test with a significant level of $5 \%$. The following is a recapitulation of the final normality test as follows:

Table 3. Recapitulation of the final normality test

\begin{tabular}{ccc}
\hline Data & Learning Outcomes & Conclusion \\
\hline Lo & 0,102 & Normal distribution \\
Ltabel & 0,142 & \\
\hline
\end{tabular}

Based on the data in table 2 that at the level of $5 \%$ and $n=26$ obtained L_0 $(0.102)<\mathrm{L}$ table $(0.142), \mathrm{H} \_0$ is accepted, indicating that the data comes from a normally distributed population. After testing the data and data analysis requirements, it shows that learning outcomes are normally distributed. Then, testing the hypothesis. Hypothesis testing in this study is calculated using the one-party t-test technique to determine the difference in the average pretest and posttest learning outcomes.

Table 4. One-party t-test results

\begin{tabular}{cccc}
\hline Respondents & $\mathbf{t}_{\text {count }}$ & $\mathbf{t}_{\text {table }}$ & Conclusion \\
\hline 26 & 9,698 & 1,706 & H0 ditolak \\
\hline
\end{tabular}

Based on table 3, it shows that after applying the assisted individualization team model assisted by Ludo media there is a difference in the average value of student learning outcomes. It is proven that with $\mathrm{db}=\mathrm{n}-1=25$ and a significance level of $5 \%$, the t-table is 1.706 . From the calculation, it is obtained that $t$ count is 9,698 . Based on the criteria $t$ count $>t$ table, namely 9.698> 1.706 so that $H_{-} 0$ is rejected and H_a is accepted. This means that there are differences in the learning outcomes of the fourth-grade students of SD Negeri 01 Petanjungan. It is known that there are differences in student learning outcomes seen from their problem-solving abilities. The test is then carried out by calculating the two-party t-test.

Table 5. Two-party t-test results

\begin{tabular}{cccc}
\hline Respondents & $\mathbf{t}_{\text {count }}$ & $\mathbf{t}_{\text {table }}$ & Conclusion \\
\hline 26 & 8,000 & 1,671 & H0 ditolak \\
\hline
\end{tabular}

Based on the calculation of the two-party t-test obtained t_hitung $=8,000$. From the list of tables with dk $\left(n_{1}+n_{2}-1\right)=51$ with a significant level of $5 \%$. Then the obtained t table $=1.671$. The results of the $t$ test calculation obtained tcount $>$ ttable, namely 8,000> 1,671. Based on these results, H_0 is rejected and H_a is accepted. This means that there is a difference between student learning outcomes with high problem-solving abilities and student learning outcomes with low problem-solving abilities after using the learning model of Team Assisted Indivialization assisted by Ludo media. 
Table 6. Study Completeness Test Results

\begin{tabular}{ccccc}
\hline No. & $\begin{array}{c}\text { Learning } \\
\text { Outcomes }\end{array}$ & Level of completeness & \multicolumn{2}{c}{ Percentage } \\
\hline & & & Completed & Not complete \\
\cline { 3 - 4 } 1 & Pretest & $75 \%$ & $11,5 \%$ & $88,5 \%$ \\
2 & Posttest & $75 \%$ & $80,8 \%$ & $19,2 \%$ \\
\hline
\end{tabular}

The percentage of student learning completeness shows that learning without using the Team Assisted Individualization model with Ludo media is $11.5 \%$ of students who complete and as many as $88.5 \%$ of students who do not complete, then after being treated using the Team Assisted Individualization model with Ludo media as many as $80,8 \%$ of students who completed and $19.2 \%$ of students who did not.

The difference in research treatment applied Team Assisted Individualization model with Ludo media and by applying conventional learning. In conventional learning, students are passive because they only listen to the material presented by the teacher. Students tend to accept the material presented by the teacher. Conventional learning activities make students feel bored quickly in learning. Conventional learning, where learning tends to be only the dominant teacher, makes students feel bored so that when learning takes place a lot of students play (Widiana \& Dkk, 2018; Wungguli \& Yahya, 2020). It is also in accordance with opinion from (Qondias \& Dkk, 2016; Sobron, Bayu, Rani, \& Meidawati, 2019) stated that if conventional learning is applied continuously it will affect student motivation. In contrast to implementing the Team Assisted Individualization learning model with Ludo media, it has a more positive impact on the learning process. This is influenced by several factors, namely as follows.

First, the Team Assisted Individualization learning model with Ludo media has an impact on the competence of knowledge about student fraction material because it can increase student activity. The results can be seen from the active student learning process to solve the problems given in groups. The TAI learning model is a cooperative learning model that combines the advantages of cooperative and individual learning. This TAI model is designed to solve learning difficulties individually (Lestari, 2015; Siwi et al., 2019). Therefore, learning activities are more widely used to solve problems. The Team Assisted Individualization (TAI) model can make students more active in learning mathematics by forming small groups with group leaders who help group members so that they can increase student activity in learning. Research conducted by Siwi, Sudrajat, \& Wardana (2019) also showed that learning by applying the TAI type cooperative learning model can improve student learning outcomes. In addition, research conducted by (Farnika et al., 2015; Siwi et al., 2019) also stated that the Team Assisted Individualization model improves students' mathematical understanding and problem solving abilities when compared to conventional learning models.

Second, the Team Assisted Individualization model with Ludo media improves students' cooperative attitudes. Cooperation is important in the learning process because students can complement each other in increasing knowledge. Eggen and Kauchak (Pratiwi, Ardianti, \& Kanzunnudin, 2018) stated that the ability to cooperate is to politely listen to other people talk, respect other people's ideas, and support the participation of each group member. In the Team Assisted Individualization model with Ludo media, the students' ability to work together develops. This model allows students to work together and assist in exchanging or getting information (Siwi et al., 2019; Weni, Susanti, \& Jatmiko, 2016).

Third, namely the selected media use factor in the application of the Team Assisted Individualization model. The application of a model without using supporting learning media is less than perfect. Therefore, selecting a supporting media can be used by the teacher to convey information so that students are motivated in learning. Research conducted by (Irwandi, 2020; Wulandari \& dkk, 2020) stated that learning media can be used by teachers in conveying information so that students can easily understand the learning material. One of them that support the Team Assisted Individualization learning model is Ludo media. Ludo media is a modified game where each point has a question card and the addition of motivational words, with the available question's students can get used to practicing doing the questions. The use of Ludo media can motivate students to learn. This is in accordance with the research conducted by Jihan, Reffiane, \& Arisyanto (2019) which stated that Ludo game makes learning fun so that students are motivated to learn. (Hapsari \& Suminar, 2014; Nisa \& Wiryanto, 2019) also stated that Ludo media is effective in increasing student motivation in learning so that student learning outcomes increase. So it can be concluded that Ludo's learning media has a positive influence on student learning motivation so that student learning outcomes increase.

\section{Conclusion}

Based on the results of the overall study, the Team Assisted Individualization model assisted by Ludo media is effective on student learning outcomes. Based on the results of the calculation, it was found that there 
were significant differences in student learning outcomes as seen from the ability to solve. So, it can be concluded that the Team Assisted Individualization model is effective on student learning outcomes seen from the mathematics problem solving abilities of grade IV students of SD Negeri 01 Petanjungan

\section{References}

Anika, \& Fajar. (2020). Efektivitas Model Pembelajaran Kooperatif Tipe Make-A Match Dalam Meningkatkan Kompetensi Sikap Siswa dan Kompetensi Pengetahuan Siswa Pada Pelajaran IPS. Jurnal Ilmiah Sekolah Dasar, 4(1), 80-85.

Ariawan, \& Pratiwi. (2017). Eksplorasi Kemampuan Siswa Kelas Iv Sekolah Dasar Dalam Penyelesaian Soal Cerita Matematika. Jurnal Pendidikan Indonesia, 6(1), 82-95. Retrieved from https://ejournal.undiksha.ac.id/index.php/JPI/article/view/9184/6327. 82-95

Donas Ahmad Najib \&Elhefni. (2016). Pengaruh Penerapan Pembelajaran Bermakna (Meaningfull Learning) Pada Pembelajaran Tematik IPS Terpadu Terhadap Hasil Belajar Siswa Kelas III di MI Ahliyah IV Palembang. JIP: Jurnal Ilmiah PGMI, 2(1), 19-28.

Donas, \& Elhefni. (2016). Pengaruh Penerapan Pembelajaran Bermakna (Meaningfull Learning) Pada Pembelajaran Tematik IPS Terpadu Terhadap Hasil Belajar Siswa Kelas III di MI Ahliyah IV Palembang. JIP: Jurnal Ilmiah PGMI, 2(1), 19-28.

Farnika, Ikhsan, \& Sofyan. (2015). Peningkatan Kemampuan Pemahaman Dan Pemecahan Masalah Matematis Sekolah Menengah Atas Dengan Model Pembelajaran Kooperatif Tipe Team Assisted Individualization. Jurnal Elemen Program Studi Matematika, 1(2), 144-152. Retrieved from http://ejournal.hamzanwadi.ac.id/index.php/jel/article/view/146

Hapsari, \& Suminar, R. (2014). Efektifitas Ludo Words Game (LWG) terhadap Peningkatan Kosakata Bahasa Inggris pada Anak Studi Kasus Pada Siswa Kelas IV SD Muhammadiyah 4 Pucang. Jurnal Fakultas Psikologi Universitas Airlangga. Retrieved from http://journal.unair.ac.id/download-fullpapers-01 Iriani Indri Hapsari, Efektifitas Ludo Words Game.pdf

Irwandi. (2020). Penggunaan Media Audio Visual Dalam Peningkatan Hasil Belajar Materi Rukun Iman Pada Siswa Kelas I SD Negeri 49 Kota Banda Aceh. Pionir Jurnal Pendidikan, 9(1), 25-44.

Ismayani, Ani, \& Nuryanti. (2016). Penerapan Project Based Learning dalam Pembelajaran Matematika untuk Meningkatkan Kemampuan Komunikasi Matematis dan Aktivitas Belajar Siswa. Prosiding.

Jihan, Reffiane, \& Arisyanto. (2019). Pengembangan Media Ludo Raksasa Pada Tema Selalu Berhemat Energi Untuk Meningkatkan Motivasi Belajar Siswa Kelas IV Sekolah Dasar. Mimbar PGSD Undiksha, 7(2), 107-113.

Kartika, \& Dkk. (2017). Pengaruh Model Pembelajaran PBL Berbantuan Media Gambar Terhadap Hasil Belajar IPA Pada Siswa Kelas V. E-Journal PGSD Universitas Pendidikan Ganesha, 5(2), 1-11.

Lestari, K. E. (2015). Penelitian Pendidikan Matematika. Bandung: PT Refika Aditama.

Mahendra, E. (2017). Project Based Learning Bermuatan Etnomatematika Dalam Pembelajar Matematika. $\begin{array}{llll}\text { Jurnal Pendidikan } & \text { Indonesia, } & \text { Retrieved } & \text { from }\end{array}$ https://ejournal.undiksha.ac.id/index.php/JPI/article/view/9257/6329

Marliani. (2015). Peningkatan Kemampuan Berpikir Kreatif Matematis Siswa melalui Model Pembelajaran Missouri Mathematics Project (MMP). Jurnal Ilmiah Pendidikan MIPA, 5(1), 14-25. https://doi.org/https://doi.org/10.30998/formatif.v5i1.166

Mufida, \& Wiyatmo. (2018). Pengembangan Media Pembelajaran Permainan Ludo Untuk Meningkatkan Penguasaan Materi Dan Minat Belajar Fisika Peserta Didik SMA. Jurnal Pendidikan Fisika UNY.

Nisa, \& Wiryanto. (2019). Pengaruh Penggunaan Media Ludo Terhadap Hasil Belajar Matematika Materi Bangun Ruang Siswa Kelas V SD. Jurnal Penelitian Pendidikan Guru Sekolah Dasar, 7(3), 2909-2919. Retrieved from https://jurnalmahasiswa.unesa.ac.id/index.php/jurnal-penelitianpgsd/article/view/28029/25644

Nurfitriana. (2015). Pengembangan Permainan Monopoli Berbasis CAI Sebagai Media Pembelajaran Pada kompetensi Dasar Menganalisis Jabatan. Jurnal Pendidikan Administrasi Perkantoran, 7(4), 51-58.

Pratiwi, I. A., Ardianti, S. D., \& Kanzunnudin, M. (2018). Peningkatan Kemampuan Kerjasama Melalui Model 
Project Based Learning (Pjbl) Berbantuan Metode Edutainment Pada Mata Pelajaran Ilmu Pengetahuan Sosial. Refleksi Edukatika : Jurnal Ilmiah Kependidikan, 8(2). https://doi.org/10.24176/re.v8i2.2357

Puspita, N. M., Asri, I. A. S., \& Ardana, I. K. (2019). Pengaruh Model Pembelajaran Kooperatif Tipe Scramble Berbantuan Media Video Animasi Terhadap Kompetensi Pengetahuan PPKn. Media Komunikasi FPIPS, 17(2), 1-10. https://doi.org/10.23887/mkfis.v17i2.22221

Qondias, \& Dkk. (2016). Pengembangan Media Pembelajaran Tematik Berbasis Mind Mapping SD Kabupaten Ngada Flores. Jurnal Pendidikan Indonesia, 5(2), 176--182. Retrieved from https://ejournal.undiksha.ac.id/index.php/JPI/about

Renny, Sonbay, Yohana, R. (2019). the Effect of Open-Ended Teaching Model on Mathematics. 1(2), 105-110.

Shoimin. (2014). Model Pembelajaran Inovatif Dalam Kurikulum 2013. Yogyakarta: Ar-Ruzz Media.

Siwi, Sudrajat, \& Wardana. (2019). Keefektifan Model Team Assisted Individualization Berbantu Media Corong Hitung Terhadap Hasil Belajar Matematika. Mimbar PGSD Undiksha, 7(2), 128-134. Retrieved from https://ejournal.undiksha.ac.id./index.php/JJPGSD/article/view/17557/10535

Slameto. (2010). Belajar dan Faktor-Faktor Yang Mempengaruhinya. Jakarta: Rineka Cipta.

Sobron, A. ., Bayu, Rani, \& Meidawati. (2019). Persepsi Siswa Dalam Studi Pengaruh Daring Learning Terhadap Minat Belajar IPA. SCAFFOLDING: Jurnal Pendidikan Islam Dan Multikulturalisme, 1(2), $30-38$.

Suarsana, Supawidhiasih, \& Parwati. (2018). The Use Of Portfolio Assessment To Overcome The Weakness Of Scientific Approach. Jurnal Pendidikan Indonesia, 7(1). https://doi.org/10.23887/jpiundiksha.v7i1.10394

Sudharto, D. (2013). Pengantar Ilmu Pendidikan (IKIP PGRI SEMARANG, ed.). Semarang.

Sundayana, \& Rostina. (2014). Media Dan Alat Peraga Dalam Pembelajaran Matematika. Bandung: Alfabeta.

Susanto, A. (2016). Teori Belajar \& Pembelajaran di Sekolah Dasar. Jakarta: Prenadamedia Group.

Trisnawati, T. (2019). Journal Of Matematics Learning. 37-45.

Weni, Susanti, \& Jatmiko. (2016). Implementasi Model Pembelajaran Kooperatif Tipe Tai (Team Assisted Individualization) Untuk Meningkatkan Hasil Belajar Fisika Siswa Sma Pada Materi Elastisitas. Jurnal Penelitian Fisika Dan Aplikasinya (JPFA), 6(1), 26-33. Retrieved from https://journal.unesa.ac.id/index.php/jpfa/article/view/882/671 06,01 2016

Widiana, \& Dkk. (2018). The Effectiveness of Tradional Game-Based Communication Learning Activity For Cognitive Process Dimension Learning Achievement. Cakrawala Pendidikan, 1(2), 260-269.

Wulandari, \& Dkk. (2020). Pengembangan Pembelajaran Blended Pada Mata Kuliah Ahara Yoga Semester II di IHDN Denpasar. Jurnal Edutech Undiksha, 8(1), 1-15. Retrieved from https://ejournal.undiksha.ac.id/index.php/JEU/article/view/26459/15780

Wungguli, D., \& Yahya, L. (2020). Pengaruh Penggunaan Media Berbasis Information and Communication Technology (ICT) terhadap Hasil Belajar Siswa pada Materi Dimensi Tiga. Jambura Journal of Mathematics Education, 1(1), 41-47. https://doi.org/10.34312/jmathedu.v1i1.5376

Yusuf, M. (2015). Asessmen dan Evaluasi Pendidikan. Jakarta: Prenadamedia Group. 